\section{ECONOMICS}

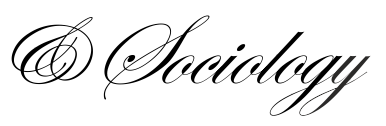

Gutović, T., Relja, R., \& Popović, T. (2020). The constitution of profession in a sociological sense: An example of sports management. Economics and Sociology, 13(4), 139-153. doi:10.14254/2071-789X.2020/13-4/9

\title{
THE CONSTITUTION OF PROFESSION IN A SOCIOLOGICAL SENSE: AN EXAMPLE OF SPORTS MANAGEMENT
}

\author{
Tea Gutović \\ Faculty of Humanities and Social \\ Sciences, University of Split, \\ Split, Croatia \\ E-mail:tgutovic@ffst.hr \\ ORCID 0000-0003-0713-4610
}

\section{Renata Relja}

Faculty of Humanities and Social

Sciences, University of Split,

Split, Croatia

E-mail: rrelja@ffst.hr

ORCID 0000-0002-5684-4558

\section{Toni Popović}

Faculty of Humanities and Social

Sciences, University of Split,

Split, Croatia

E-mail: thopovic1@,ffst.hr

ORCID 0000-0003-1881-489X

Received: February, 2020

1st Revision: September, 2020

Accepted: December, 2020

DOI: $10.14254 / 2071-$

789X.2020/13-4/9

JEL Classification: D02, O17, P31
ABSTRACT. In this paper, the field of sports management is considered through the prism of the sociology of professions. The authors start from the hypothesis that sports management is currently a semi-profession due to it missing some of the classical elements highlighted within sociological literature. It is primarily about professional associations that define the rules of conduct, making professions more or less autonomous. Besides, higher education for sports managers is becoming increasingly desirable, but it is still not mandatory, which is a sine qua non of a true professionalization. The possibility of high earnings leads to various affairs that can weaken the reputation of the profession, and diminish the trust of the public in sports managers. For the professionalization of the field, persistence in the development of professional associations, that would bring the codes of ethics and occupational standards is necessary. Establishing quality educational programs requires recognizing the potential of sport-based entrepreneurship, intending to balance market trends and the needs of athletes, audiences, and the community.

\section{Introduction}

Keywords: sports managers, profession, professional associations, sport-based entrepreneurship.

Sport has grown beyond the sphere of leisure and entertainment to become one of the leading industries within the global economy. The management of sports organisations, primarily clubs, requires specific knowledge, skills and competences that are up to date with market trends. Education in the field of sports management is becoming an imperative for 
successful participation in sports business, as well as a prerequisite for the acknowledgment of this occupation as a true profession. Managers develop the market, taking on the tasks of business planning, organising, leading and controlling (Robbins, Coulter, 2002; Barros, Alves, 2003). Whether in the context of recreational or professional sport, management is defined as highly desirable but at the same time sociologically under-researched field of work (Barcelona, 2004).

In everyday terms, being professional means providing quality work, being paid for it or not. On the other hand, sociology defines professions as occupations that share some common features. These can be long-term education, altruistic orientation, the existence of professional associations that determine professional socialisation, as well as high social status and income (Smerić, 2005; Reis Monteiro, 2015; Relja, Popović, Gutović, 2019). Sociological reflections on the importance of professions are based on the prerequisites of secularisation and rationalisation of the society, as well as on the development of a knowledge society through increasing investment in education, science and technology (Santrić, 1990; Chandrasekhar, 2006). A significant growth in the number of professions has been recorded after the Second World War due to the expansion of the public sector and the social welfare system and the reorientation of the economy towards the service and quaternary sector. Increasingly specialised science and education systems have affected the creation of entirely new integrated professions that play a central role in social decision-making. They can therefore be said to represent the creative and reflexive drivers of society, maintaining its level of scientific, technological and social development (Beck, 2001).

Sport can be viewed as an important social sphere in which most people participate, either as professional athletes or amateurs, coaches, managers, recreational athletes or serve as the audiences. It affects the society, and the accumulation of knowledge within this sphere is connected to wider social processes. Sport represents a 'miniature of society'. The scientific approach to sport makes it possible to analyse the processes of specialisation of jobs, knowledge distribution, rationalisation and commercialisation (Markula, 2014; Földesi, 2014; Maguire, 2014).

The general opinion within sociology is that professions are occupations which assume a prominent role in the social division of labour. They are often associated with elitism and ranked highest in the occupational stratification. Within this paper, sports management is explored as a specific type of profession and entrepreneurship, which can generate desirable results and profits, by encouraging the creativity and innovation of participants in sport. As a field of study, sports management consists of a respectable body of knowledge and literature concerning both theory and practice (economy, psychology, etc.), of numerous professionals who are educated for managerial positions and who pass on their knowledge to others, as well as professional associations that reflect credibility and readiness for effective action under existing socioeconomic conditions (Pitts, 2001). Managers assume leading roles in sports organisations, taking on the responsibility for their development, and in return they are enjoying high incomes and reputation. The question arises to what extent sports management can be discussed as a profession in sociological terms and in what way the elements of a profession are constructed within the sphere of sports?

The paper starts from the hypothesis that sports management is currently a semiprofession. Some of the classical sociological elements of the profession have not yet achieved complete affirmation, although their growing importance is noticed (e.g., compulsory and effective higher education, recognizable professional associations whose provisions would be binding, etc.) (Dowling, 2018). To explore the given hypothesis in more detail, a qualitative review of literature was conducted using Web of Science, Scopus and Google Scholar databases. The paper is organized into two sections. First, a professionalization' process in the 
context of sports management is considered. The focus is on its desirable elements, as well as the inseparable entrepreneurial features for achieving sports and financial success. Second, the main findings of the review are summarized, with a discussion on further professionalization of sports management. The paper concludes with recommendations for future research on the related topics.

\section{Literature review}

\section{Basic elements of sports management as a profession}

The conceptual framework for the study of this topic was established in the 1970s. In addition to a prescriptive analysis of elements that steer the development of a particular type of occupation into a profession, it is necessary to carry out a process analysis that clarifies the corresponding point of development within a particular social environment (Čulig, 1999a). Emphasis is placed on the meaning of the profession, thus mitigating the atemporality of the prescriptive elements. Within the sphere of sport, related sociological literature addresses the theory of sports medicine (Safai, 2005; Malcolm, 2006; Theberge, 2009), whereas several studies deal with the work of coaches (Walk, 1997; 2004; Rynne, Mallett, Tinning, 2006; Duffy et al., 2011; Griffo et al., 2019). In general, research of professions is based on the postulates of sociology, management and organisational studies. In this sense, we can talk about a specific sociological approach to management as a profession. Sports management has been considered an occupation ever since first sports and recreational activities were organised, so it is quite a paradox that one of the oldest jobs ever is at the same time one of the more recent areas of interest in terms of professionalization (Pitts, 2001).

In sociology, the structural-functional approach consists in analysing the presence of the following essential attributes of a profession: 1) high degree of theoretical knowledge and problem-solving competence, 2) primary orientation to the community interest rather than to individual self-interest, 3) the existence of professional codes of ethical conduct and professional associations, 4) a system of rewards for professional work achievement (Barber as cited in Santrić, 1990). These can easily be translated into (1) authority, (2) altruism, (3) autonomy and (4) attractiveness of a profession. In this paper, it is important to consider the process approach as well, which within different forms (neo-Weberian approach, interactionism, etc.) criticises the functionalist idealisation of professions. Their meaning within a specific social environment should not be ignored, as well as the frequent challenges of professionalization such as financial affairs, conflicts of interest, etc. (Kuhlmann, 2013).

Becoming an authority in the sphere of knowledge is acquired through higher education, i.e. an academic degree, which has a socio-cultural value. The specialisation of sports management as an academic discipline has accompanied the development of sport and the sports industry (Stockdale, Cormier, 2014). The reputation of a profession is manifested precisely in the demanding education, but also in the type of institutions offering such education (Čulig, 1999b). Between 1949 and 1959, the University of Florida offered a program for sports administration in baseball, and the first program for sports administration in general was launched at Ohio University a few years later (in 1966). The standardisation of university curricula conducted in the USA in the early 2000s resulted in 16 approved study programs, with additional 12 programs awaiting approval. Criticism of previous programs was directed towards the subject of their study. It actually involved teaching physical education under the guise of sports administration and management (Pitts, 2001). The existence of a long-term challenge in this sense had already been pointed out in research from the late 1980s on the lacking quality 
of curricula for sports managers due to their close connection with the education for the coaching occupation (Parkhouse, 1978; 1979).

Determining the quality of sports management curricula requires placing the occupation within one of the two existing currents of opinion. The first defines it as limited to organisation (club) management (narrower approach) and the second as encompassing all aspects of sportbased management (broader approach) (Pitts, 2001). The development of sports management as an academic discipline, but also as a specific area of business, is inextricably linked to the globalisation of the sports industry. Therefore, the standard career path from an athlete through coach to manager without the appropriate career education is no longer enough. There is a growing need for specialised knowledge in the fields of economy, sociology, psychology and kinesiology. The development of specific occupational standards and corresponding curricula, as well as critical discussions on the matter ever since the late 1980s have been leaning towards the concept of sports management in the broader sense, i.e. leadership and management within the sports industry in general (Meek, 1997; Miragaia, Soares, 2017).

A competency-based formal education model has come to be recognized as an important prerequisite for a wider presence of highly competent sports managers. Several sources highlight the necessity of differentiating between curricula at the undergraduate and the graduate level in a way that the former should provide the basic training for beginners, whereas the latter should include more specific knowledge aimed at increasing the quality and credibility of the business (Hardy 1987; Jamieson, 1987; DeSensi et al., 1990; Kjeldsen, 1990; Cuneen, 1992; Pitts, 2001). An example of an interdisciplinary curriculum model was presented in 1986 at the First Conference of the North American Society for Sport Management, after which corresponding education programs increasingly began to include proportionate amounts of sports culture, media communication, psychology, kinesiology and economics courses. To date, such curricula are focused on keeping pace with social development and changes in sport, thus providing future managers with a necessary professional basis of knowledge, skills and competencies, industry-focused specialisation and practical experience (Jamieson, 1987; Kelley et al., 1994; Çiftçi, Gökçel, Demirkıran, 2015). ${ }^{1}$ More recent literature indicates the need for greater reflection on the actual professional practice of sports managers aimed at maintaining a high level of success in both sports results and financial performance (Edwards, 1999; Miettinen, 2000; Bower, 2014; Miragaia, Soares, 2017).

The orientation of sports managers towards the community, as the next defining attribute of a profession, is primarily reflected in their immediate activities on the market. They take on leading positions in sports organisations in which both audiences and athletes are important stakeholders. More often than not they are also the ones to initiate training and education programs aimed at raising awareness of healthy living, as well as various promotional activities to improve the general quality of life of the community through health care, physical activity and nutrition. Certain parallels can be drawn between the approach to sports management as a profession and management in schools. In this context, literature on the inclusion of different actors in the decision-making process and the transformation of an autonomous leader into an individual highly involved in processes within the narrower (professional) and wider (social) community is to be noted (Bush, Glover, 2014; Alfirević, Petković, Gutović, 2017). Including a greater number of actors / stakeholders (audiences, civil society organisations, local government, schools, etc.) into the decision-making process leads to decisions which are based on the practical needs of the community. Managers don't always

\footnotetext{
${ }^{1}$ Higher education sports management programs are available worldwide, and examples of curricula can be found on the official websites of: the EU Business School Barcelona, University of Applied Sciences Europe - Iserlohn, Berlin and Hamburg, Croatian University College Aspira, University College Birmingham, University of Kent, Kansas State University, University of Canberra, etc.
} 
have a clear understanding of the community and the possibilities of its development. In such circumstances, the involvement of other stakeholders is of great benefit.

Traits of altruism are to some extent acquired as early as during internships, which have become a frequent form of entry into the job market for sports managers. In such a way, as a number of authors have pointed out, the cognitive and moral development of individuals is stimulated (Dees, Hall, 2012; Hardin et al., 2013; Miragaia, Soares, 2017). The focus is on linking academic knowledge and market interests with projects of significance for the sports and social community. While some research shows that internships lead to lower levels of expected satisfaction with the future career, a lower level of commitment to the occupation and a decreased interest in professional sports management (Cunningham et al., 2005), there is no doubt that internships may represent an important catalyst of positive impacts on the community as an essential part of the profession (McKelvey, Southall, 2008; Pauline, 2013; Miragaia, Soares, 2017). Good management and leadership implemented and encouraged by a manager helps develop his/her club in the direction of a "learning organisation". Such mentoring gives students i.e. interns the opportunity to recognize, create and take advantage of business and sports opportunities. Without collective reflection in practice and constantly striving for progress, which is primarily inspired by a manager and achieved by all of the members of an organisation involved, nothing more than mediocrity with no significant results can be achieved (Brandon-Lai, Armstrong, Bunds, 2016).

Managers do not only manage sports organisations, but also the future of athletes, recreational players, audiences and other stakeholders in the sports industry, so it is crucial to place emphasis on their business ethics. The development of business ethics as an essential element of the profession (Čulig, 1999b) is highlighted as one of the objectives of their education. As part of a sports management curriculum, students are informed on the importance of cultural norms and values, practices and ultimately of business ethics. Education creates transferable skills which can be applied in organizational practice. While there is no official code of ethics for the entire sports management industry, shaping managers as "good citizens" is one of the fundamental educational objectives. The imperative of ethical conduct is further emphasised in the ability to achieve a balance between market demands and altruistic i.e. community-oriented behaviour (Kelley et al., 1994; Hums, 2010; Newman, 2014; Miragaia, Soares, 2017).

Čulig (1999a; 1999b) highlights the existence of professional associations as one of the essential elements of the profession. Where they exist, sports management associations may have a code of ethics that defines the professional relationship with the competent professional organisation, clubs, athletes and society as a whole. ${ }^{2}$ Furthermore, sports managers help in framing sports legislation by working in task groups to create proposals, as well as by participating in workshops, public meetings and discussions as a target group. However, their influence on the creation of professional ethics is best seen in their compliance with laws and other provisions. The reason for the adoption of regulatory documents is to move away from the ideology of professionalism as we are aware of numerous affairs in the sports arena due to the increasing opportunities for high profits (Maennig, 2005; Andreff, 2016). By participating in the drafting of laws relating to sport, in addition to drafting codes of ethics, which is still quite a rare practice,

\footnotetext{
2 This, for example, includes the provisions of the North American Sport Management Association's Code of Ethics, which is available online. Internationally, similar associations that provide advisory support to its members (national associations, branch organisations, etc.) and promote best practices in sports management, also exist in Australia, Asia, Europe, Africa and Latin America. Some authors emphasise the importance of expanding national associations that would adopt codes of professional ethics focused on modes of acquisition of professional knowledge and skills, licensing, maintaining discipline within the profession, etc., with the possibility of adapting their provisions depending on the type of sport (Ibrahim, 2016). In this context, it is of central importance to evaluate the effectiveness of the code in promoting motivation for ethical action (Waegeneer, Devisch, Willem, 2016).
} 
sports managers help to establish their own profession by ensuring its autonomy through creating a legal framework for sports.

Reflecting on the Weberian point of view, which sees them as a means of achieving their members' interests, one of the objectives of professions can be to maximize privileges. Strategies such as highly demanding and expensive education, the necessity of obtaining special licenses issued by professional bodies and other (non-)material requirements may constitute "excessive" professionalization with a questionable connection to actual job requirements. Such forms of occupational closure give precedence to members of specific professional bodies over others who are not part of that group. These are primarily people who may intend to become members, as well as citizens who may be paying unjustified prices for exclusive professional services (Andrews, Wærness, 2011). The exclusivity of practice protected by legal norms creates a clear distinction between professional and unprofessional work which is prohibited (Abercrombie, Hill and Turner, 2006). The Weberian approach rejects the exclusive presence of certain idealising elements of a profession. It is based on a comprehensive analysis of the actors, strategies, power relations, as well as knowledge- and practice- claims associated with the institutionalisation of a profession in the (inter)national context (Faulconbridge, Muzio, 2011). Observing both the micro and macro level of society, this and other modern process approaches take into consideration the prescriptive elements presented by functionalists, critically studying them within a given context in relation to specific actors (e.g. members of a profession, citizens, professional associations, government, labour organisations, international bodies, etc.). In doing this they aim to explore how a particular profession is created in a specific space and time (e.g. a current topic are doctors, lawyers, nurses, school principals, military officers, etc.).

However, professions are not only marked by ethical practices, but also by severe ethical breaches, as demonstrated by numerous examples from some of the above-mentioned recognized professions (financial affairs, inappropriate behaviour towards clients, favourable treatment of government and corporate representatives, etc.). All of this can result in diminished citizens' trust and reputation of professions as a possible problem affecting both the quality of life and the sense of security in a society (Groenewegen, 2006; Dingwall, 2008; Riska 2010). Occupational closure is present in the field of sports management as well, in the form of sports organizations which define business norms and practices (e.g. clubs, federations, etc., in addition to sports management associations that are not yet widespread) (Pitts, 2001; Dowling, 2018). The process approach emphasises that although this can safeguard the interests of professionalism and professional jurisdictions, it also contributes to the creation and maintenance of monopoly to specific activities. Positive developments include the knowledge and authority of professional sports managers for leadership and management in sports, which have been gaining in importance. On the other hand, an alternative hypothesis may view this field as an exclusive social function, the role of which is moving away from the needs of the sports community and society as a whole. Sports management as a profession must be approached from the perspective of process formation, i.e. critical evaluation of its prescriptive elements. These actually change over time depending on the type of sport; actors adapt them to their specific knowledge and needs, and more or less also to the needs of the wider community.

Finally, social capital represents an important factor of occupational closure, as well as an individual's ability of overcoming it. Sports managers are rooted in the socioeconomic context of the industry, in which their social interactions and connections are formed. The assumption of exclusive access to individuals from the sphere of sport, retired athletes or coaches is becoming less valid in the light of globalisation of the sports industry, growing importance of financial capital, open access to education and accessibility of online or digital learning materials (Horch, Schütte, 2003; Todd, Andrew, 2008; Maguire, 2015). Becoming a sports manager is today possible for anyone who chooses to get an education in this field. Nevertheless, long-term success and career 
highly depend on the acquisition of social capital and networking within a particular sport (Barros, Alves, 2003; Elmose-Østerlund, van der Roest, 2017). The diversity of social interactions as an element of social capital highlights the need to reflect on modern sport as a form of entrepreneurship founded on cooperation, risk-taking, competitiveness, creativity and innovation.

\section{Sport as an entrepreneurial arena}

The mission of a manager is almost identified with the role of a promoter of an organisation's knowledge. There is a distinct need for such education due to changes in the workforce structure in general and the reorganisation of labour from mass Fordism to flexible Post-Fordism. New jobs give advantage to educated individuals, ready to participate creatively in organisational decision-making (rigid hierarchy models are abandoned). Successful managers are expected to have a business vision and to be able to coordinate tasks by delegating responsibilities to others, i.e. by facilitating change in a dynamic environment. Professional identities are increasingly framed around logics of efficiency and commerce. Consequently, the aim of modern education is to create an entrepreneurial culture in all walks of the society, shaping a uniquely competitive individual willing to take risks, network, learn and adapt to social and economic changes (Brown, Lauder, Ashton, 2008; Muzio, Brock, Suddaby, 2013).

Most education programs in sport-based entrepreneurship focus primarily on sports management. Sports managers take on the role of entrepreneurs, who by their very definition convert ideas into innovations and create and pursue business opportunities. Such entrepreneurship is manifested on an individual level through the public recognition of managers, as well as at the collective level of an organisation building its prosperity on interactions with the sports environment and other successful businesses (Ratten, 2010; 2011a). Examples of managers basing business practices on democratic decision-making, creativity and innovation are a beacon to be followed in the development of the sports industry in general.

The positive impacts of the connection between sports and entrepreneurship were clearly demonstrated during the global recession at the beginning of the century, when the sports industry recorded a drop in financing much like all other areas of the economy (Ciletti, 2012). This is a specific sphere of business which includes an element of symbolic connection of the audiences with an organisation (club), as well as personal interactions including displays of emotion (Chalip, 2004). The created entrepreneurship model must aim to nurture all such relationships, both in professional and amateur sport alike. In professional sport, athletes are often treated as a commodity on the open market with a particular financial and social value which depends on the success of their sporting results. Amateur sport, on the other hand, remains in the realm of leisure and is not exposed to commercialisation to such an extent. The basis of the entrepreneurial approach is the focus on the type and level of sport involved, accompanied by the consideration of both audiences' interest and the physical and mental abilities of athletes. In the light of that, it is pivotal to strike a balance between economic, social and human needs (Cordery, Davies, 2016). 


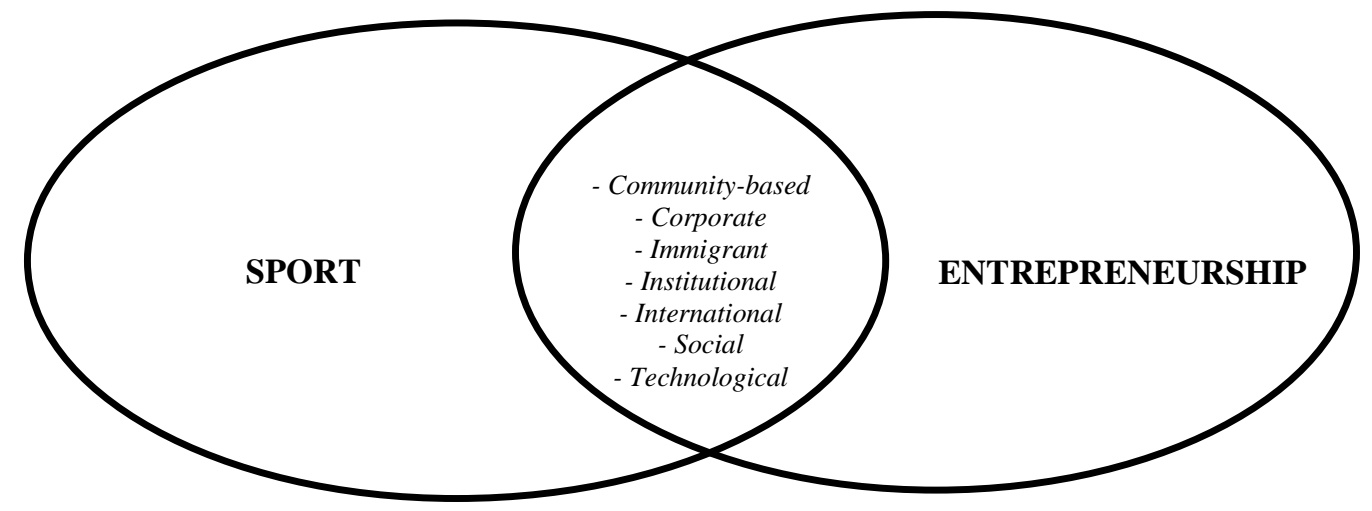

Figure 1. Sport-based entrepreneurship categories Source: adapted from Ratten (2011a)

There is an evident need for an entrepreneurial approach to management in the development of new forms of business, but also in enhancing the quality of work and the overall performance of sports clubs (Ball, 2005). Urban proliferation, exposure to mass media, democratisation of the public and private spheres and economic development have been some of the factors that have impacted the expansion of the sports market and the universal sportification of society. Sport as an entrepreneurial arena is an area of development of numerous forms of entrepreneurship (Figure 1), each of which applies economic principles and creates new trends in its own way. Social entrepreneurship, for example, reinvests some of the profits according to the needs of the community, the environment or vulnerable population groups. Corporate entrepreneurship can be utilised to promote brands and products, whereas immigrant entrepreneurship promotes social integration processes. In any case, all the mentioned types of entrepreneurship can affect the performance of clubs, either in the form of greater popularity, increased profit, new player transfers or improved results. A growing form of sports entrepreneurship is also the development of new sports using information technology that creates virtual player communities and new markets, which in turn demonstrates the importance of social support in the construction of sports reality. In addition to new forms of entrepreneurship, the development of all the dynamic aspects of sport-based entrepreneurship creates the basis for the expansion of the sports industry into one of the world's leading markets (Figure 2) (Ratten, 2011a).

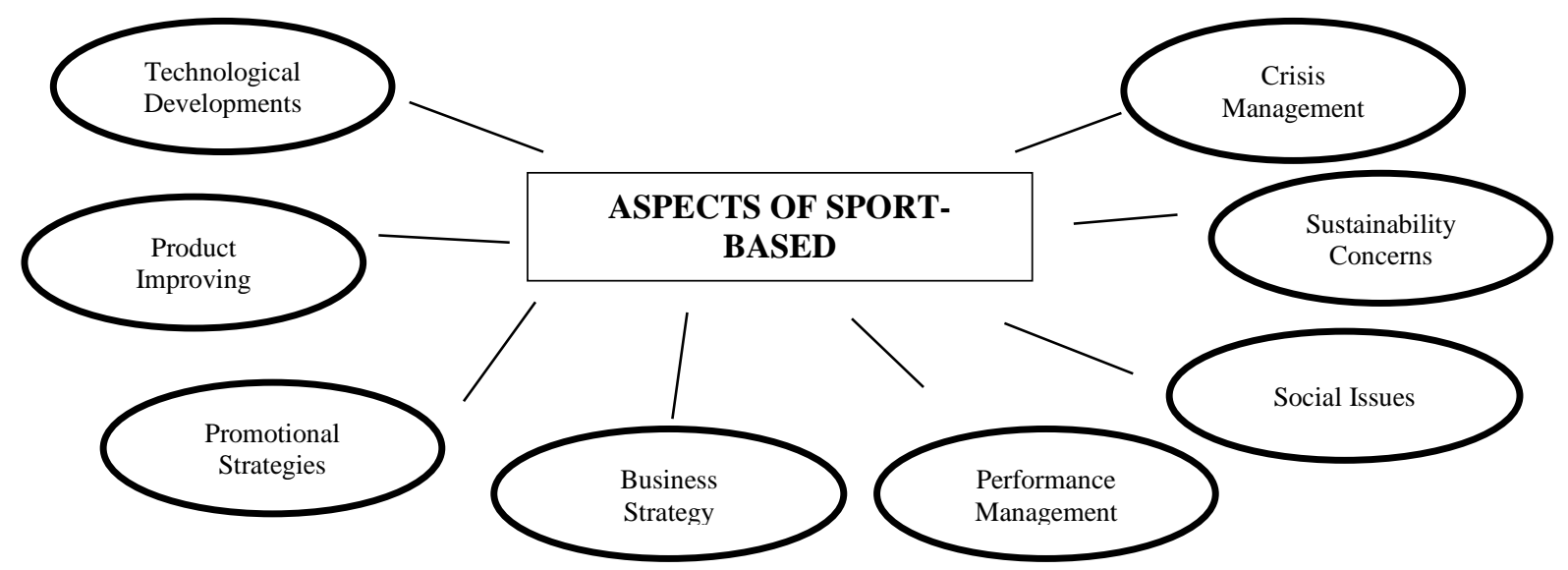

Figure 2. Dynamic aspects of sport-based entrepreneurship Source: adapted from Ratten (2011a) 
Sports organisations demonstrate innovation by applying new technologies, improving products and using innovative promotional approaches. New technologies are often presented for the first time at sporting events, and new forms of technology-based promotion are an essential element of 21st century sport (Ciletti, 2012; Ratten 2010). Elements of proactiveness are manifested in the implementation of new leadership and management strategies that increase the competitiveness of a business. The embeddedness of sports organisations in society makes them increasingly focused on the needs of the community. Meeting the different needs of the audiences, being attentive to sustainability concerns and environmental problems are some of the examples of how sports management ensures the market value, competitiveness and currency of their sports organizations (Ratten, 2011b; 2014; Bjärsholms, 2017).

As an inevitable aspect of modern society, the problem of risks is a matter of interest of different sociological interpretations. Risks are taken by almost all actors, participating in the sports industry either passively or actively, from the audience, through players and coaches to managers. Through the concept of reflexive modernity, Giddens sees risk as an essential part of a social structure open to change (Giddens, 2002). Risk management is an important area of sports management, be it economic, sports or safety risk. Such risk primarily involves material or result impacts caused by athletes' injuries or the departure of coaches due to an insufficient level of education as required by law (Dimitriadi, Dimitriadi, 2007). Further risks include sponsorship availability, audience safety, as well as investing in players in view of the uncertainty of their results (Ratten, 2010; 2011a). Successful clubs usually apply a risk management model involving ongoing assessment, as well as management evaluation, to correct any possible errors and increase financial and sporting performance.

Sport inevitably delivers new value. In this sense, it is akin to entrepreneurship, which does so by definition, regardless of whether it creates innovations of a sociocultural or economic nature. Combining these two spheres of business is becoming a challenge in both practice and research dedicated to the interest of society, audiences and employees in sport.

\section{Generalization of the main statements and discussion}

A central issue concerning the credibility of sports management involves the matter of its placement in an appropriate academic and business area. Professional literature available goes in two basic directions. The first includes physical education, an area of study within kinesiology, while the second refers to economics, primarily concerning the fields of organisational management and leadership (Pitts, 2001). In this paper, sports management is discussed in the wider sense, as a profession in sociological terms, which implies the implementation of entrepreneurial practices. Through their own competencies, knowledge and skills, as well as through networking with the sports environment and successful companies, managers boost the competitiveness of sports organizations and business innovation.

The central question raised is whether sports management can be considered a profession. If the concept is approached from the functionalist point of view, it is necessary to determine its essential attributes, which include authority, altruism, autonomy and attractiveness. The authority of sports managers is based on an academic degree in the field, which provides them with an appropriate level of expertise. Although many managers are not professionally educated yet, such education is becoming an imperative as evidenced by the growing number of higher education sports management programs in the world. In addition, managers attend various forms of lifelong learning related to their job. Community interest (altruism) is manifested with regard to a diversity of sports actors (recreational athletes, students, professional athletes, audiences, etc.) and by taking into account their needs and attitudes within the decision-making process. The attractiveness of the profession is reflected 
in the high financial rewards and the social status enjoyed by sports managers. What is very questionable in terms of the functionalist approach to the professionalization of sports management is its autonomy, i.e. the insufficient number and participation of professional associations in the creation of binding codes of professional ethics. Also, taking into account the process approach, it is necessary to highlight the ability of professions to adapt to the social, or in the case of sports managers - the sports and business context. Such adaptation can even involve illicit innovations in the sense of the Mertonian typology of responses, as demonstrated by match-fixing scandals in Italian A-league football and the American NBA basketball league, as well as the FIFA corruption affair, etc. Such actions are contrary to altruism as an essential element of the profession, which, in addition to the authority of knowledge, leads to public trust and justifies the high social status and incomes enjoyed by professionals in the field.

The implications of this paper indicate that sports management is perceived as a semiprofession, only developing into a true profession. Primarily, it is due to a lack of autonomy of the occupation, and compulsory and effective high education as well. Semi-professions have certain essential attributes of professions, while they lack others (Šporer, 1990). Nursing as well as the occupations of school principals and social workers are often given as examples of semiprofessions with limited autonomy and with lower incomes than those in sports management. Sport affects the society, so a feedback loop is understandable in shaping the sphere of sport itself. Currently, the associated management is almost entirely dependent on legislative bodies, ministries and sports federations, and is losing autonomy due to a lack of profiled professional associations. Greater effort in establishing them is necessary. Such organizations should create and promote standards of compulsory education for sports managers and professional ethics, in addition to entrepreneurship practices and the development of the sports industry (Dowling, 2018). Quality education is a prerequisite for a greater share of competent managers. Codes of ethical practice, with the possibility of banning those who do not adhere to them, can further promote the interests of all sports stakeholders, not just clubs (or some managers).

What contributes to the development of the sports industry, under the leadership of (semi-)professional management, is its perception as an entrepreneurial arena. Business is approached flexibly and innovatively, by creating opportunities and taking risks. It is precisely what sports managers of today are like, more or less aware of the fact that in addition to selling sports products, they also deal with people and their careers and destinies. Globalisation has increased interest in the sports industry, with many of the sports organisations of today operating as financial moguls in a number of business sectors (Ratten, 2012). Future considerations of sports management and sport in general should be directed towards analysing entrepreneurial practices and creating new markets. An emphasis must be placed by the sociological community on this semi-profession as being inseparable from entrepreneurship in the pursuit of business and sports achievements.

\section{Conclusion}

Guidelines for the sociological study of sports management as a profession are presented in this paper. Despite the abundant literature within the fields of kinesiology and economics, sociologists have not paid significant attention to this occupation. One of the reasons is the relatively recent development of sport as a total social fact that permeates all social strata, not just the elite (Žugić, Delija, 1997). Its importance in contemporary society is clearly reflected in its status as one of the leading economic sectors. For example, in the last twenty years alone, the number of people using Health Clubs has doubled in America, while more than $70 \%$ of children under the age of eleven have been involved in some team sport (Rani, 2016). When it comes to the audiences, they are measured in tens of millions of people around the world when 
it comes to the NBA, while football is considered to be "the world's most important unimportant thing." These are some notable examples of popularization and economic potential of sports.

The career of a sports manager can be pursued in various spheres, for example within sports clubs, sports centers, universities, schools, professional associations and sports federations, as a sports media commentator or sports agent, etc. In such circumstances is not surprising that the World Association for Sports Management, which was founded ten years ago, today includes international offices on all inhabited continents. These organizations insist on the professionalization of sports managers. Some of the central issues are the development of professional ethics and raising the quality of academic programs. The interdependence of the quality of sport and its management has been recognized (Rani, 2016).

Previous findings show the importance of further sociological research of sports management. Certainly, it is necessary to respect the social context, but also the differences between sports, as required by the process approach. In other words, it is necessary to explore the meaning of the profession in a particular environment (assumed levels of necessary knowledge and altruism, funding of managers, the role of their social status, etc.). Research projects should also fund comparative studies to find best practice solutions (especially for curriculum content, running of sports organizations and the work of professional associations) (Relja, Popović, Gutović, 2019).

Given the many academic programs designed to educate sports managers, the topic of their quality is very current. In this sense, it is possible to compare their content with the recommendations of professional bodies, the attitudes of participants about the programs, but also the differences in entrepreneurship and stakeholder orientations between managers who attended them and those who did not. More frequent research on initiatives of establishing professional associations in sports management is needed as well. Their emergence is observed internationally. However, they are still not common. We consider them to be a basis for the systematic professionalization of sports management due to their important role in encouraging this process.

\section{References}

Abercrombie, N., Hill, S., \& Turner B. S. (2006). The Penguin Dictionary of Sociology. London: Penguin Books Ltd.

Alfirević, N., Petković, S., \& Gutović, T. (2017). Psychological and Sociological Determinants of Educational Management and Leadership in Croatia and Bosina and Herzegovina: Results of Empirical Research. DIEM: Dubrovnik International Economic Meeting, 3(1), 382-392.

Andreff, W. (2016). Corruption in Sport. In Byers, T. (Ed.), Contemporary Issues in Sport Management: A Critical Introduction (pp. 46-65). London, Thousand Oaks, New Delhi, Singapore: SAGE Publications.

Andrews, T. M., \& Wærness, K. (2011). Deprofessionalization of a female occupation: Challenges for the sociology of professions. Current Sociology, 59(1), 42-58.

Ball, S. (2005). The Importance of Entrepreneurship to Hospitality, Leisure, Sport and Tourism. The Higher Education Academy. Hospitality, Leisure, Sport and Tourism Network. 1-14.

Barcelona, B. (2004). Examining the Importance of Recreational Sport Management Competencies Based on Management Level, Agency Type, and Organizational Size. Recreational Sports Journal, 28(1), 45-63. DOI: 10.1123/rsj.28.1.45

Barros, C. P., \& Alves, M. P. (2003). Human Capital Theory and Social Capital Theory on Sports Management. International Advances in Economic Research, 9(3), 218-226. 
Beck, U. (2001). Pronalaženje političkoga - prilog teoriji refleksivne modernizacije. Zagreb: Jesenski i Turk.

Bjärsholm, D. (2017). Sport and Social Entrepreneurship: A Review of a Concept in Progress. Journal of Sport Management, 31(2), 1-41. DOI: 10.1123/jsm.2017-0007

Bower, G. G. (2014). Theory and practice: Utilizing Dewey's experiential learning theory to implement a 5k road race. Journal of Hospitality Leisure Sport \& Tourism Education, 15, 61-67. DOI: 10.1016/j.jhlste.2014.06.001.

Brandon-Lai, S. A., Armstrong, C. G., \& Bunds, K. S. (2016). Sport Management Internship Quality and the Development of Political Skill. Journal of Applied Sports Management, 8(3), 96-111.

Brown, P., Lauder, H., \& Ashton, D. (2008). Education, Globalisation and the Future of the Knowledge Economy. European Educational Research Journal, 7(2), 131-156. DOI: 10.2304/eerj.2008.7.2.131

Bush, T., \& Glover, D. (2014). School leadership models: What do we know? School Leadership \& Management, 34(5), 553-571.

Chalip, L. (2004). Beyond impact: A general model for host community event leverage. In Ritchie, B., Adair, D. (Eds.), Sport tourism: interrelationships, impacts and issues (pp. 226-251). Clevedon: Channel View Publications.

Chandrasekhar, C. P. (2006). Who Needs a „Knowledge Economy“: Information, Knowledge and Flexible Labour. Social Scientist, 34(1/2), 70-87.

Çiftçi, S., Gökçel, S., \& Demirkıran, Y. (2015). Analyse of the Expectations of the Sports Management Students in Terms of Quality. Procedia: Social and Behavioral Sciences, 174, 2602-2609.

Ciletti, D. (2012). Sports entrepreneurship: a theoretical approach. In Ciletti, D., Chadwick, S. (Eds.), Sports entrepreneurship: theory and practice (pp. 1-10). Morgantown: Fitness Information Technology.

Cordery, C. J., \& Davies, J. (2016). Professionalism versus amateurism in grass-roots sport: Associated funding needs. Accounting History, 21(1), 98-123.

Cuneen, J. (1992). Graduate-Level Professional Preparation for Athletic Directors. Journal of Sport Management, 6, 15-26.

Cunningham, G. B., Sagas, M., Dixon, M., Kent, A., \& Turner, B. A. (2005). Anticipated Career Satisfaction, Affective Occupational Commitment, and Intentions to Enter the Sport Management Profession. Journal of Sport Management, 19, 43-57.

Čulig, B. (1999a). Profesijska edukacija: procjene i aspiracije. Croatian Sociological Review, 30(3-4), 211-227.

Čulig, B. (1999b). Sociologija kao studij i struka. Empirijska analiza jedne populacije. Croatian Sociological Review, 30(1-2), 19-43.

Dees, W., \& Hall, T. (2012). Creating experiential learning opportunities for sport management students: The case of grand slam marketing. Sport Management Education Journal, 6, 71-80.

DeSensi, J., Kelley, D., Blanton, M., \& Beitel, P. (1990). Sport management curricular evaluation and needs assessment: A multifaceted approach. Journal of Sport Management, 4, 31-58.

Dimitriadi, A., \& Dimitriadi, S. (2007). A Conceptual Model of Risk Management and its Importance for Sport and Leisure. Choregia: Sport Management International Journal, $3(1): 19-25$.

Dingwall, R. (2008). Essays on Professions. Hampshire, Burlington: Ashgate.

Dowling, M. (2018). Exploring Sport Management as an Academic Profession: A Critical Review of Occupational Theory. Journal of Global Sport Management, 3(4), 321-338. 
Duffy, P., Hartley, H., Bales, J., Crespo, M., Dick, F., Vardhan, D., Nordmann, L., \& Curado, J. (2011). Sport coaching as a 'profession': challenges and future directions. International Journal of Coaching Science, 5(2), 93-123.

Edwards, A. (1999). Reflective Practice in Sport Management. Sport Management Review, 2 , 67-81.

Elmose-Østerlund, K., \& van der Roest, J-W. (2017). Understanding social capital in sports clubs: participation, duration and social trust. European Journal of Sport and Society, 14(4): 366-386.

Faulconbridge, J. R., \& Muzio, D. (2011). Professions in a globalizing world: Towards a transnational sociology of the Professsions. International Sociology, 27(1), 136-152.

Földesi, G.S. (2014). Assessing the sociology of sport: On world inequalities and unequal development. International Review for the Sociology of Sport, 50(4-5), 442-447. DOI: $10.1177 / 1012690214547142$

Giddens, A. (2002). Odbjegli svijet - kako globalizacija oblikuje naše živote. Zagreb: Jesenski i Turk.

Griffo, J. M., Jensen, M., Anthiny, C. C., Baghurst, T., \& Hodges Kulinna, P. (2019). A decade of research literature in sport coaching (2005-2015). International Journal of Sports Science and Coaching, 14(2), 201-215. DOI: 10.1177/1747954118825058

Groenewegen, P. (2006). Trust and the sociology of the professions. European Journal of Public Health, 16(1), 3-6.

Hardin, R., Bemiller, J., \& Pate, J. (2013). Development and organization of a student-operated sport management cocurricular club: Partners in sports. Sport Management Education Journal, 7(1), 43-50. DOI: 10.1123/smej.7.1.43

Hardy, S. (1987). Graduate curriculums in sport management: The need for a business orientation. Quest, 39, 207-216.

Horch H., \& Schütte, N. (2003). Competencies of sport managers in German sport clubs and sport federations, Managing Leisure, 8(2), 70-84. DOI: 10.1080/1360671032000085684

Hums, M. A. (2010). The conscience and commerce of sport management: One teacher's perspective. Journal of Sport Management, 24(1), 1-9.

Ibrahim, L. Y. (2016). Ethical Issues And Professional Code Of Conduct As Moral And Social Obligations For Sports Management Practitioners In Nigeria: A Paper Work. European Journal of Physical Education and Sport Science, 2(3), 15-28.

Jamieson, L. M. (1987). Competency-Based Approaches to Sport Management. Journal of Sport Management, 1, 48-56.

Kelley, D. R., Beitel, P. A., DeSensi, J. T., \& Dale Blanton, M. (1994). Undergraduate and Graduate Sport Management Curricular Models: A Perspective. Journal of Sport Management, 8, 93-101.

Kjeldsen, E. K. M. (1990). Sport Management Careers: A Descriptive Analysis. Journal of Sport Management, 4, 121-132.

Kuhlmann, E. (2013). Sociology of Professions: Towards International Context-Sensitive Approaches. South Africa Review of Sociology, 44(2), 7-17.

Maennig, W. (2005). Corruption in International Sports and Sport Management: Forms, Tendencies, Extent and Countermeasures. European Sport Management Quarterly, 5(2), 187-225.

Maguire, J. (2014). Assessing the sociology of sport: On globalization and the diffusion of sport. International Review for the Sociology of Sport, 50(4-5), 519-523.

Malcolm, D. (2006). Unprofessional Practice? The Status and Power of Sport Physicians. Sociology of Sport Journal, 23, 376-95. 
Markula, P. (2014). Assessing the sociology of sport: On sport and exercise. International Review for the Sociology of Sport, 50(4-5), 536-541. DOI: 10.1177/1012690214539958

McKelvey, S., \& Southall, R. M. (2008). Teaching sport sponsorship sales through experiential learning. International Journal of Sport Management and Marketing, 4(2-3), 225-254.

Meek, A. (1997). An estimate of the size and supported economic activity of the sports industry in the United States. Sport Marketing Quarterly, 6(4), 15-21.

Miettinen, R. (2000). The concept of experiential learning and John Dewey's theory of reflective thought and action. International Journal of Lifelong Education, 19(1), 54-72. DOI: $10.1080 / 026013700293458$.

Miragaia, D. A. M., \& Soares, J. A. P. (2017). Higher education in sport management: A systematic review of research topics and trends. Journal of Hospitality, Leisure, Sport \& Tourism Education, 21(A), 101-116. DOI: 10.1016/j.jhlste.2017.09.001

Muzio, D., Brock, D. M., \& Suddaby, R. (2013). Professions and Institutional Change: Towards an Institutionalist Sociology of the Professions. Journal of Management Studies, 50(5), 699-721.

Newman, J. I. (2014). Sport without management. Journal of Sport Management, 28(6), 603615. DOI: $10.1123 /$ jsm.2012-0159.

Parkhouse, B. (1978). Professional preparation in athletic administration and sport management: Graduate programs in the United States. Journal of Physical Education and Recreation, 49, 22-27.

Parkhouse, B. (1979). Analysis of graduate professional preparation in sport management. Athletic Administration, 14, 10-24.

Pauline, G. (2013). Engaging students beyond just the experience: Integrating reflection learning into sport event management. Sport Management Education Journal, 7(1), 1-12.

Pitts, B. G. (2001). Sport Management at the Millennium: A Defining Moment. Journal of Sport Management, 15, 1-9.

Rani, D. (2016). Sports Management and Opportunities for Professional Development. IOSR Journal of Sports and Physical Education, 3(4): 31-36.

Ratten, V. (2010). Developing a theory of sport-based entrepreneurship. Journal of Management \& Organization, 16, 557-565. DOI: 10.1017/S1833367200001930

Ratten, V. (2011a). Sport-based entrepreneurship: towards a new theory of entrepreneurship and sport management. International Entrepreneurship and Management Journal, 7(1), 57-69. DOI: $10.1007 / \mathrm{s} 11365-010-0138-\mathrm{z}$

Ratten, V. (2011b). Social entrepreneurship and innovation in sports. International Journal of Social Entrepreneurship and Innovation, 1(1), $42-54$.

Ratten, V. (2012). Sport entrepreneurship: challenges and directions for future research. International Journal of Entrepreneurial Venturing, 4(1), 65-76.

Ratten, V. (2014). Sport innovation: the role of social entrepreneurship and creativity in fostering sport related business activities (abstract). The Research Colloquium on Societal Entrepreneurship and Innovation at RMIT, October 2014.

Reis Monteiro, A. (2015). The Teaching Profession: Present and Future. Cham, Heidelberg, New York, Dordrecht, London: Springer.

Relja, R., Popović, T., \& Gutović, T. (2019). Analysis of Elements and Process of School Principals' Professionalization in Croatia. Management: Journal of Contemporary Management Issues, 24(Special Issue), 55-71. DOI: $10.30924 / \mathrm{mjcmi} .24 . \mathrm{si} .4$

Riska, E. (2010). Health Professions and Occupations. In Cockerham, W. C. (Ed.), The New Blackwell Companion to Medical Sociology (pp. 337-354). Malden, Oxford, West Sussex: Blackwell Publishing Ltd. 
Robbins, S. P., \& Coulter, M. (2002). Management (7th Edition). Upper Saddle River: Prentice Hall.

Rynne, S. B., Mallett, C., \& Tinning, R. (2006). High Performance Sport Coaching: Institutes of Sport as Sites for Learning. International Journal of Sports Science and Coaching, 1(3), 223-234.

Safai P. (2005). The Demise of the Sport Medicine and Science Council of Canada. Sport History Review, 36, 91-114.

Santrić, V. (1990). Osnovni tokovi i problemi profesionalizacije zanimanja: slučaj sestrinstva. Croatian Sociological Review, 21(2), 311-339.

Smerić, T. (2005). Sparta usred Babilona: sociologijski aspekti vojne profesije. Zagreb: Hrvatska sveučilišna naklada.

Stockdale, M., \& Cormier, J. (2014). Bridging the Educational Gap: An Exploratory Investigation of Sport Management Students' Career Perceptions. 2014 North American Society for Sport Management Conference (NASSM 2014): Oral Presentation, May 2014.

Šporer, Ž. (1990). Sociologija profesija - ogled o društvenoj uvjetovanosti profesionalizacije. Zagreb: Croatian Sociological Society.

Theberge, N. (2009). 'We Have All the Bases Covered'. Constructions of Professional Boundaries in Sport Medicine. International Review for the Sociology of Sport, 44(2-3), 265-281. DOI: 10.1177/1012690209104795

Todd, S. Y., \& Andrew, D. P. S. (2008). An exploratory investigation of sport management students' attraction to sport jobs. International Journal of Sport Management and Marketing, 4(4), 323-337.

Waegeneer, E. D., Devisch, I., \& Willem, A. (2016). Ethical Codes in Sports Organizations: An Empirical Study on Determinants of Effectiveness. Ethics \& Behavior, 27(4), 261282.

Walk, S. (1997). Peers in Pain: The Experiences of Student Athletic Trainers. Sociology of Sport Journal, 10, 22-56.

Walk, S. (2004). Athletic Trainers: Between Care and Social Control. In Young, K. (Ed.), Sporting Bodies: Damaged Selves: Sociological Studies of Spots-Related Injury (pp. 251267). London: Elsevier.

Žugić, Z., \& Delija, K. (1997). Sociologija športa kao multiparadigmatska znanost: između scijentizma i novih spoznaja. Revija za sociologiju, 18(1-2), 83-92. 